\title{
Buffer and Salt Damage to the Filamentous Cyanobacterium Anabaena cylindrica
}

\author{
By GEOFFREY D. SMITH, ${ }^{*}$ ELIZABETH J. MACKEY AND \\ ARLENE DADAY \\ Department of Biochemistry, Faculty of Science, Australian National University, P.O. Box 4, \\ Canberra, A.C.T. 2600, Australia
}

(Received 6 April 1983; revised 8 June 1983)

The commonly used buffer HEPES was found to cause severe disintegration of the cyanobacterium Anabaena cylindrica, as measured by filament breakage, cell disruption, phycocyanin release and nitrogenase inhibition. The effect became increasingly severe as the buffer concentration was increased above $10 \mathrm{mM}$. The observed cell damage does not appear to be unique to HEPES, similar observations being made with $\mathrm{Tris} / \mathrm{HCl}$, sodium phosphate, sodium sulphate and sodium chloride. It appears that the cells are very sensitive to ionic strength.

\section{INTRODUCTION}

Growth and metabolism of cyanobacteria in closed systems frequently results in $\mathrm{pH}$ changes, thus necessitating the addition of buffers. The requirements of the buffer are simply that it has an ionizing functional group with a $\mathrm{pK}$ in the $\mathrm{pH}$ range required. Ideally the buffer should be inert as far as the biological system is concerned and fulfil certain other criteria also (Good et al., 1966; Ferguson et al., 1980). Relatively few buffers have been available for the $\mathrm{pH}$ range 6-8 and, of those tested, HEPES, introduced by Good et al. (1966), has become one of the most successful and widely used (Ferguson et al., 1980). A perusal of the recent cyanobacterial literature reveals that HEPES is overwhelmingly the most widely used buffer, both for experiments with intact cells and those with cell-free extracts. Buffer concentrations in the range 10$50 \mathrm{mM}$ are commonly used. We report here that, although $A$. cylindrica can be grown in $10 \mathrm{~mm}$ HEPES buffer, higher concentrations were damaging to cell structure and nitrogenase activity. Tris and phosphate buffers at $50 \mathrm{~mm}$ were also damaging, as were similar concentrations of other salts. It is suggested that this organism is very sensitive to elevated ionic strengths.

\section{METHODS}

Organisms and growth. Anabaena cylindrica ATCC 27899 was obtained from the American Type Culture Collection and grown as described previously (Daday et al., 1977), but with the growth medium (initial pH $7 \cdot 5$ ) at $\frac{1}{8}$ strength with respect to all components except phosphate. Cells were harvested by centrifugation $(6000 \mathrm{~g}, 10 \mathrm{~min})$ at a concentration in the range $120-150$ Klett units as measured by a Klett-Summerson colorimeter, where 100 Klett units were equivalent to $0.23 \mathrm{mg}$ dry weight $\mathrm{ml}^{-1}$. Buffers were at $\mathrm{pH} 7.5$ unless otherwise stated.

Nitrogenase assay. Nitrogenase activity was measured by the reduction of acetylene to ethylene, as described previously (Lambert \& Smith, 1980). All assays were performed in air mixed with $10 \%$ acetylene at atmospheric pressure.

Pigment measurement. Phycocyanin levels were measured from the absorbance at $620 \mathrm{~nm}$ (Myers \& Kratz, 1955).

Dry weight determination. This was done by washing $10 \mathrm{ml}$ volumes of cells with water and drying overnight at $85^{\circ} \mathrm{C}$.

Chemicals. Chemicals were of the highest available purity. HEPES was obtained either from Sigma (lot no. 71F-5041) or Calbiochem-Behring (lot no. 210127). The results were not dependent on the source of this chemical. 


\section{RESULTS AND DISCUSSION}

\section{Effect of buffers and salts on cell structure and nitrogenase activity}

In an experiment involving the assay of nitrogenase activity in $50 \mathrm{mM}-\mathrm{HEPES}$ buffer, $\mathrm{pH} 7 \cdot 5$, we were surprised to find zero activity and severe filament disruption. Nitrogenase activity (Fig. $1 a$ ) and phycocyanin release (Fig. $2 a$ ) were subsequently measured as a function of buffer concentration. Both parameters reflected increasing cell damage with increasing buffer concentrations. The observations correlated with a microscopic visual inspection of the cells: increasing buffer concentrations led to progressively more damage to the organism as seen by filament and cell disruption. A search for alternative buffers revealed that Tris and sodium phosphate produced the same trends. These observations were made both at $\mathrm{pH} 7.5$ and 6.8 and with cells transferred from $\mathrm{pH} 6.8$ medium to $\mathrm{pH} 7 \cdot 5$ HEPES buffer; qualitatively, it can be said that to this extent they were not $\mathrm{pH}$-dependent.

It appeared from these results that the cell damage and consequent nitrogenase inhibition were not due to specific buffer effects, but to ionic effects, and similar results were obtained with other salts, including sodium sulphate and sodium chloride (Figs 1 and 2). The results were in no way due to osmotic effects: sorbitol, at concentrations up to $50 \mathrm{mM}$, produced no visible cell damage nor phycocyanin release (Fig. $2 a$ ). Interestingly, increasing sorbitol concentrations progressively inhibited nitrogenase activity (results not shown), a result for which we offer no explanation. Most of the damage was progressive with time and hence Figs 1 and 2 are arbitrary in this sense. The time course of phycocyanin release induced by sodium sulphate and HEPES (Fig. 3) was to some extent variable from one batch of cells to another and also from one lot of cells to another within a given population, as observed microscopically. The susceptibility to these ionic effects seemed to be somewhat dependent on the age and concentration of the cultures, and also with the amount of mucilage excreted by the cells. In the reported experiments the various buffers and salts were simply made up in water (at $\mathrm{pH} 7.5$ ), but similar results were obtained in the presence of the medium (results not shown).

The ionic strength of a salt solution, $I$, is defined as $I=\frac{1}{2} \Sigma m \mu^{2}$, where $m=$ molar ionic concentration and $\mu=$ ionic charge. When the abscissa scales of Figs $1(a)$ and $2(a)$ were normalized to ionic strength (Figs $1 b$ and $2 b$ ) the curves became much closer together, indicating that a large part of the observed effects was due simply to ionic strength. However, the curves do not completely superimpose and hence it can be assumed that specific ions also influenced the results to a greater or lesser degree. It is well known, for example, that di- and trivalent ions bind more readily to proteins than do uni-univalent salts.

It may be concluded from these results that using HEPES or Tris buffers at concentrations

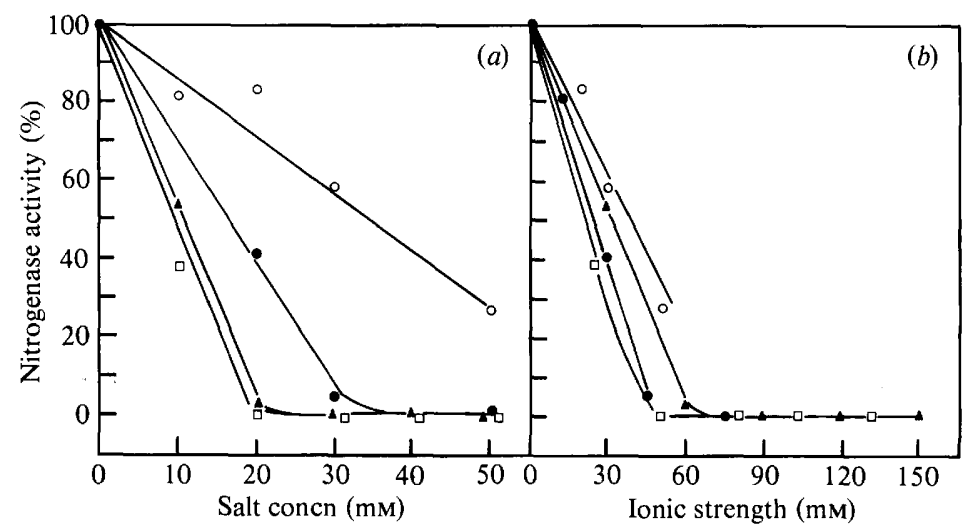

Fig. 1. Nitrogenase inhibition by HEPES (O), $\mathrm{NaCl}(\mathrm{O})$, sodium phosphate $(\square)$ and sodium sulphate $(\boldsymbol{\Delta})$. Results are expressed relative to a control without added buffers or salts and are given as a function of the molar concentration $(a)$ and ionic strength $(b)$. Activity was measured as an initial rate $5 \mathrm{~h}$ after the addition of the salts. Cell concentrations were in the range 120-150 Klett units. 


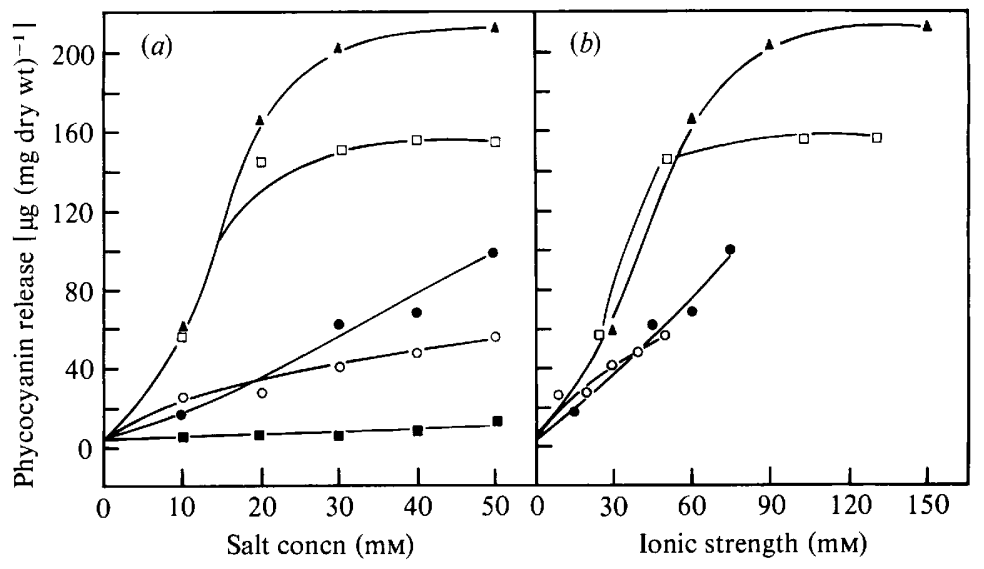

Fig. 2. Phycocyanin release as a function of the buffer or salt concentration $(a)$ or as a function of ionic strength $(b)$, for $\mathrm{HEPES}(\mathbf{O}), \mathrm{NaCl}(\mathrm{O})$, sodium phosphate $(\square)$, sodium sulphate $(\mathbf{A})$ and sorbitol $(\square)$. Measurements were made $5 \mathrm{~h}$ after adding the salts. Cell concentrations were in the range 120 150 Klett units.

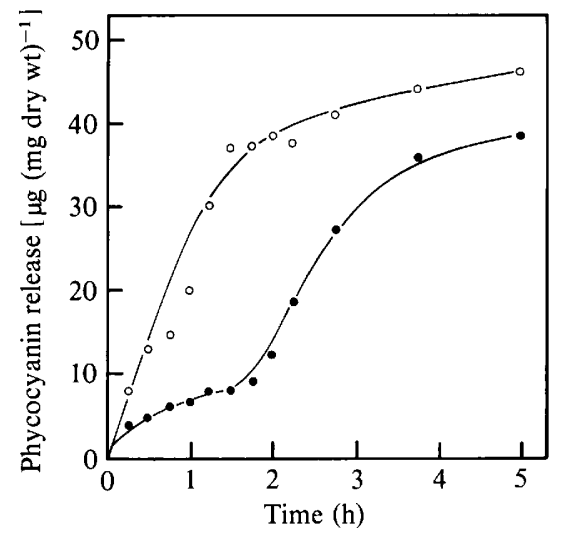

Fig. 3. Time course of phycocyanin release after suspending cells to 120 Klett units in sodium sulphate (O) or HEPES buffer (O) (both $50 \mathrm{~mm}$ ).

above $10 \mathrm{~mm}$ with certain filamentous cyanobacteria is hazardous and for such organisms phosphate buffers should not be used even at this concentration. This is likely to create problems in many experiments where such a concentration provides insufficient buffering capacity. However, cyanobacteria clearly show different susceptibilities to ionic strength. For example, HEPES at $20 \mathrm{~mm}$ had no significant effect on the growth rate of Oscillatoria redekei and Aphanizomenon flos-aquae (Smith \& Foy, 1974). Also marine organisms have presumably adapted to higher ionic strengths; Anabaena sp. CA, for example, grows optimally at $75 \mathrm{~mm}$ $\mathrm{NaCl}$ (Stacey et al., 1977).

We are not the first to report buffer effects on cyanobacteria. Bothe et al. (1977) reported total vegetative cell destruction at high $(100 \mathrm{mM})$ concentrations of phosphate and Ferguson et al. (1980) reported growth inhibition of Anabaena variabilis by HEPES and other buffers, although the growth rate was still $50 \%$ of the control even in 100 mM-HEPES. Bridges \& Ward (1976) reported inhibition of photosynthetic oxygen evolution from Agmenellum quadruplicatum by phosphate, TES and Tris buffers. The conclusion of these workers, that inhibition occurs at the level of photosystem II, seems unnecessarily restrictive in view of the general nature of the damage caused by buffers and other salts reported herein.

This work was supported by a grant from the Australian Research Grants Scheme (Grant D2-76/15666). 


\section{REFERENCES}

Bothe, H., Tennigkeit, J. \& Eisbrenner, G. (1977). The utilization of molecular hydrogen by the bluegreen alga Anabaena cylindrica. Archives of Microbiology 114, 43-49.

BRIDGES, S. \& WARD, B. (1976). Effect of hydrogen ion buffers on photosynthetic oxygen evolution in the blue-green alga, Agmenellum quadruplicatum. Microbios 15, 49-56.

Daday, A., Platz, R. A. \& SMith, G. D. (1977). Anaerobic and aerobic hydrogen gas formation by the blue-green alga Anabaena cylindrica. Applied and Environmental Microbiology 34, 478-483.

Ferguson, W. J., BraunschWeiger, K. I., BraunschWEIGER, W. R., SMITH, J. R., MCCORMICK, J. J., Wasmann, C. C., Jarvis, N. P., Bell, D. H. \& Good, N. E. (1980). Hydrogen ion buffers for biological research. Analytical Biochemistry 104, $300-310$
Good, N. E., Winget, G. D., Winter, W., CoNNOLLY, T. N., IZAWA, S. \& SiNGH, R. M. M. (1966). Hydrogen ion buffers for biological research. Biochemistry 5, 467-477.

LAMberT, G. R. \& SMrth, G. D. (1980). Hydrogen metabolism by filamentous cyanobacteria. Archives of Biochemistry and Biophysics 205, 36-50.

MYERS, J. \& KRATZ, W. A. (1955). Relationships between pigment content and photosynthetic characteristics in a blue-green alga. Journal of General Physiology 39, 11-22.

SMITH, R. V. \& FoY, R. H. (1974). Improved hydrogen ion buffering of media for the culture of freshwater algae. British Phycological Journal 9, 239-245.

Stacey, G., Van BaAlen, C. \& Tabita, F. R. (1977). Isolation and characterization of a marine Anabaena sp. capable of rapid growth on molecular nitrogen. Archives of Microbiology 114, 197-201. 